\title{
Glycoforms of Human IgG in Health and Disease
}

\author{
健常時と病態におけるヒト IgG のグライコフォーム
}

\author{
Jefferis, Roy \\ Molecular Immunology at the University of Birmingham \\ Edgbaston, Birmingham B15 2TT, UK
}

Key Words: Antibody therapeutics, Glycosylation, IgG-Fc effector activities, IgG-Fc stability, Microcalorimetry

\begin{abstract}
More than twenty recombinant antibody molecules are now licensed for treatment of a variety of cancers and chronic diseases. In addition there are, literally, hundreds in development and early phase clinical trials. Initially, the attraction of antibodies was their specificity for target antigens; however, it is now appreciated that the immune complexes formed trigger downstream biological activities that are critical to clinical success. It has been demonstrated that, although accounting for only $2-3 \%$ of antibody mass, glycosylation of the IgG-Fc is essential to the activation of such biologic mechanisms (effector functions). Additionally the precise structure of the attached oligosaccharide can determine protein conformation and stability and hence downstream biologic efficacy. Cellular engineering has been embraced to generate cell lines that synthesise selected homogeneous antibody glycoforms that may be optimal for a given disease indication. The advantage of being able to formulate therapeutic antibody preparations at high concentration might be aided by additional glycosylation within the IgG-Fab region. Novel production vehicles are also being developed that offer the possibility of lower production costs, with consequent lower cost of goods.
\end{abstract}

\section{A. Introduction}

The origin of my interest in the influence of glycosylation on the structure and functional activities of human immunoglobulin $\mathrm{G}$ (IgG) glycoproteins results from fortuitous collaborations with Professor Noriko Takahashi. Initial contact was made through Prof. Yoji Arata, then at the University of Tokyo, when I attended the Fifth International Congress of Immunology, held in Kyoto in 1983. I took advantage of the opportunity to contact Prof. Arata because of related interests, particularly his expertise in nuclear magnetic resonance (NMR) and the assignment of chemical shifts to individual histidine residues within the IgG-Fc. We agreed that I should submit some of our materials to his laboratory for further
要 旨

今や 20 種類以上のリコンビナント抗体が，様々ながんや 慢性疾患の治療用に認可されている。さらに, 文字通り数百 もの抗体が開発あるいは臨床の早期フェーズのさなかにあ る。当初, 抗体の魅力は標的抗原への特異性にあった。しか し今や，免疫複合体の形成が臨床上の成否を決する下流の生 物活性の引き金となることが広く認められている。そのよう な生物学的メカニズム（エフェクター機能）の活性化には, 抗体の質量のわずか 2-3\%にすぎない糖鎖による IgG-Fc の修 飾が不可欠であることが示されている。さらに，Fcに結合し ている糖鎖の構造はタンパク質のコンフォメーションや安定 性を決定し, それにより下流の生物学的な効力にも影響を及 ぼし得るのである。ある疾患に対して最適となるような均一 なグライコフォームの抗体を選択的に生産する細胞株を作り 出すために細胞工学的な手法が取り入れてられてきている。 治療抗体を高濃度に調製することには利点があるが，IgG$\mathrm{Fab}$ 領域に新たな糖鎖修飾を行うことが，それを支援する技 術となるかもしれない。また，生産コストを下げることによ って低廉化をもたらし得る生産系も開発されつつある。

\section{A はじめに}

私が，ヒト免疫グロブリン $\mathrm{G}(\mathrm{IgG})$ の構造と機能に対す る糖鎖修飾の影響に興味を抱いたそもそものきっかけは高橋 禮子教授と思いがけない共同研究を行ったことである。彼女 との初めてのコンタクトは，1983 年に京都で行われた第 5 回 免疫国際議会に参加した際に, 当時東京大学の荒田洋治教授 を通じて実現された。核磁気共鳴 (NMR) に造詣が深く IgG -Fcの個々のヒスチジン残基の化学シフトの帰属を行なって いた荒田教授と私は興味が関連していたため，私は彼と接す る好機に乗じたのだった。荒田教授のさらなる NMR 研究の ために，私は彼の研究室に試料を送ることに同意した。私は まさにそれを実行したが，その後長いこと音沙汰がなかっ 
NMR studies. I duly did so; however, there followed an extended period of "silence". When a draft manuscript did arrive it reported oligosaccharide profiles for the proteins we had supplied but no NMR data. As a prelude to NMR structural studies the oligosaccharide profiles had been determined by Noriko Takahashi. This led to the first of 16 joint publications, dating from 1987-2007.

Following this first collaboration we agreed a programme of joint studies and I obtained funding to spend 6 weeks in Japan, mostly in the laboratory of Yoji Arata but also one week in Nagoya to gain experience of the analytical protocol that Noriko had developed. On my return we prepared a panel of monoclonal human IgG subclass proteins, isolated from the sera of patients with multiple myeloma, a cancer of plasma cells, for comparative oligosaccharide analysis. The data generated, the most complete available at that time, showed that whilst the oligosaccharides present were the same as for normal serum derived $\operatorname{IgG}$ the relative proportions of each was characteristic for each individual protein, i.e., each neoplastic clone of plasma cells (1). We experienced some difficulty in obtained acceptance of our manuscript for publication and received persistent but essentially trivial criticisms; however, the eventual publication proved definitive and signaled the entry of my laboratory into the field of glycobiology.

\section{B. Human IgG}

The human immune system is comprised of cellular and humoral components; the latter being antibodies present in blood (one of the four humours of Greek medicine) and other body fluids. We now define five classes of antibody and within the $\mathrm{IgG}$ and $\operatorname{IgA}$ classes four and two subclasses, respectively. Collectively they constitute nine isotypes that are products of different germline genes. In humans the IgG antibody class predominates in blood and equilibrates with the extra-vascular space; an essential property to deliver appropriate pharmacokinetics and pharmacodynamics. Within a natural immune response the pathogen/IgG immune complexes that are formed have potential to activate a wide range of effector functions, resulting in the removal and destruction of the complex. The four subclasses of human $\operatorname{IgG}$ are defined and enumerated according to their relative concentrations in normal serum; thus, IgG1, IgG2, IgG3 and IgG4 account for $\sim 60 \%, 25 \%, 10 \%$ and $5 \%$, respectively. Each IgG subclass exhibits a unique profile of effector functions when evaluated by in vitro assays (2-7). To date all recombinant monoclonal antibodies approved as therapeutics seek to exploit the structural and functional characteristics of the human IgG class.
た。論文の草稿が届いたとき，そこには NMR データは無 く，かわりに私たちが送ったタンパク質の糖鎖プロファイリ ングが記載されていた。NMRによる構造研究の前奏として, 糖鎖プロファイリングが高橋禮子によって行われていたのだ った。これが，1987年から 2007 年にわたって公表された 16 報の共著論文の先駆けであった。

この最初の共同研究に引き続いて, 私たちは一連の共同 研究を遂行することに同意し，私は日本で 6 週間過ごすため の研究費を獲得することができた。その大部分を荒田洋治研 究室で過ごしたが, 1 週間は名古屋に赴き, 禮子が開発した糖 鎖分析のプロトコールを学ぶ経験を得た。帰国後, 私たち は，糖鎖の比較分析のために，プラズマ細胞のがんである多 発性骨髄腫の患者血清から単離したヒトモノクローナル IgG の一連のサブクラスを用意した。得られたデータはその当時 としては最大限に完成されたものであり，健常人の血清由来 の IgG と同じ糖鎖から構成されてこそいるものの，それらの 割合は個々のタンパク質ごとに，言いかえれば形質細胞のが ん性のクローンごとに固有のものであった。この論文の公表 に対しては，本質的に取るに足りない批判を執拗に受け，な かなか受理されないという憂き目をみた。結局, 最終的に公 表された論文は世に認められ，私たちの研究室は糖鎖生物学 の分野に仲間入りしたのであった。

\section{B. ヒト $\lg G$}

ヒトの免疫システムは細胞性と体液性の成分から構成さ れている。後者は血液（ギリシアの医学の 4 つの体液のうち の 1 つ）及び他の体液中に存在する抗体にあたる。現在では 抗体は 5 種類に大別されており, さらに IgGには 4 種類, $\operatorname{IgA}$ には 2 種類のサブクラスが存在する。つまり, 抗体は異 なる生殖系列遺伝子に担われている 9 種類のアイソタイプが 存在することになる。ヒトでは IgG が血液中の抗体の大部分 を占めて抢り，血管外部の体液と均衡を保っている。この特 性は適切な薬物動態学的 · 薬物動力学的性質を担う送達を実 現するうえで不可欠である。通常の免疫応答に沶いて, 病原 体と IgGの間で形成された免疫複合体は広範なエフェクター 機能を活性化する性質を潜在的に有しており，その結果とし てそれらの複合体は除去・破壊される。ヒト IgGには 4 つの サブクラスが存在し, 正常な血清中の相対的な濃度は, IgG1 ( 60\%), IgG2 ( 25\%), IgG3 ( 10\%), IgG4 ( 5\%) の順で ある。In vitroアッセイに基づいて，それぞれの IgGのサブク ラスはエフェクター機能に関して独特なプロファイル示すこ とが分かっている（2-7）。今日までに治療薬として認可され ているリコンビナントモノクローナル抗体はいずれも, ヒト $\mathrm{IgG}$ クラスの構造的・機能的な特徵を活用しようとはかられ 


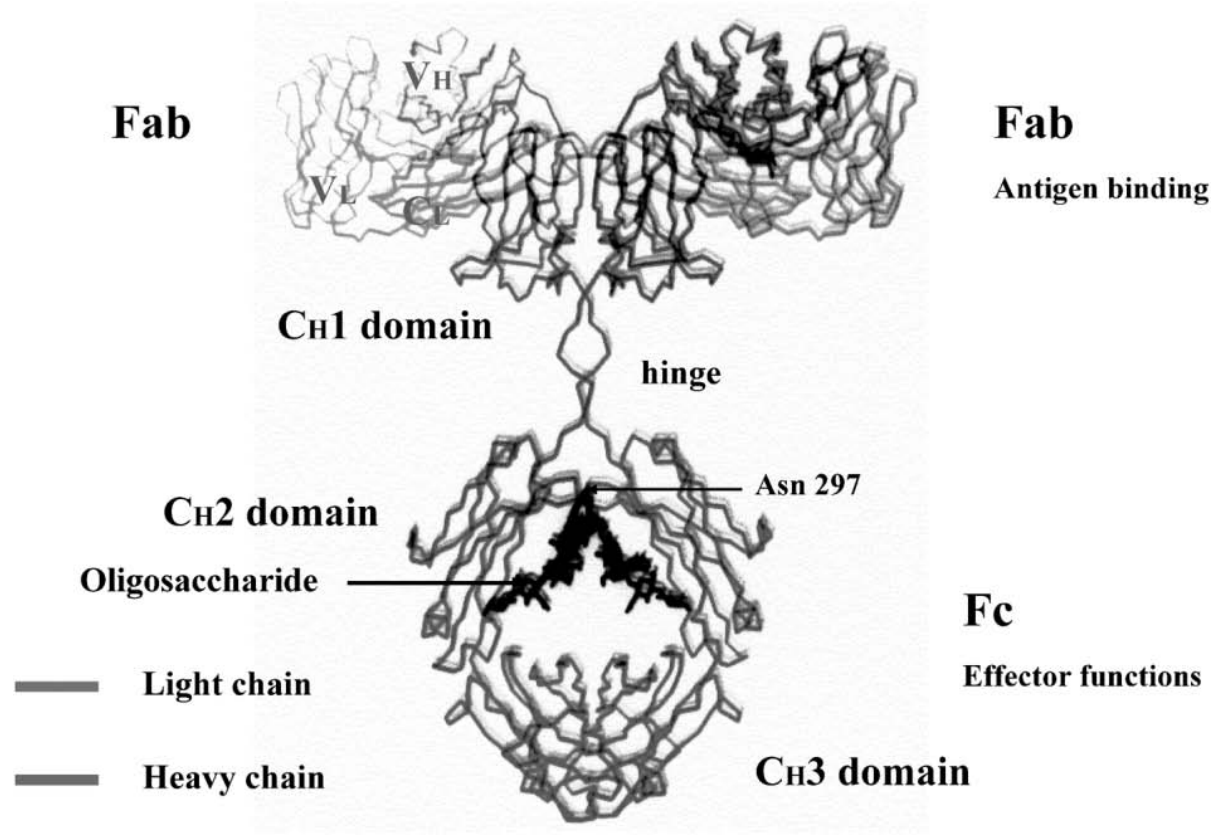

Fig. 1. $\alpha$-carbon backbone structure of the IgG molecule. Exposure to papain cleaves the hinge region to release Fab \& Fc fragments

In its simplest form an individual $\mathrm{IgG}$ molecule is composed of two identical light chains and two identical heavy chains comprised of repeating structural motifs (homology regions). The tertiary structure of each homology region defines the immunoglobulin fold or domain (2-4). Domains of the light and heavy chains pair in covalent and non-covalent association to form three independent protein moieties connected thorough a flexible linker (the hinge region) (see Fig. 1). Two of these moieties, referred to as Fab regions, are of identical structure and each expresses a specific antigen-binding site; the third, the $\mathrm{Fc}$, expresses interaction sites for ligands that activate clearance and transport mechanisms. These effector ligands include three structurally homologous cellular Fc receptor types (Fc $\gamma$ RI, Fc $\gamma$ RII, Fc $\gamma$ RIII), the C1q component of complement and the neonatal $\mathrm{Fc}$ receptor $(\mathrm{FcRn})$ (8-12); the latter determines the catabolic half-life, transport into extra-vascular space and passage across the placenta; the newborn human infant is not immuno-competent and is protected by maternal $\mathrm{IgG}$ antibody during the first 6-9 months of life. Activation of Fc receptors and the $\mathrm{Clq}$ component of complement initiate inflammatory cascades that combat and resolve episodes of infection. These activities are critically dependent on IgG-Fc $N$ linked glycosylation and, vary between different antibody glycoforms present in normal polyclonal IgG (13-15). By contrast binding to FcRn, and hence the catabolic halflife, is not dependent on antibody glycoform (3).
ている。

最も単純に表せば, $\operatorname{IgG}$ 分子は構造モチーフ（相同領域） の繰り返しからなる 2 本の同一な軽鎖と 2 本の同一な重鎖に より構成されている。相同性のあるそれぞれの領域の 3 次構 造は免疫グロブリンフォールドあるいはドメインをかたちづ くっている (2-4)。重鎖と軽鎖のドメインは共有結合抢よび非 共有結合による会合を通じて組久合わせられて抢り，柔軟性 のあるリンカー（ヒンジ領域）を介して連結された 3 つの独 立したパーツを形成している（図 1 を参照）。Fab 領域と呼ば れる2つのパーツは同一の構造をして抢り, 特異的な抗原結 合を担っている。残る 1 つのパーツは Fc とよばれ，クリアラ ンスや輸送の機構を活性化するリガンドとの相互作用部位を 有している(8-12)。こうしたエフェクターリガンドの中に は, 類似した立体構造をもつ細胞の Fcレセプター（Fc $\gamma \mathrm{RI}$, $\mathrm{Fc} \gamma \mathrm{RII}, \mathrm{F} \gamma \mathrm{R}$ IIII), 補体成分 $\mathrm{C} 1 \mathrm{q}$, 新生児の Fcレセプター (FcRn) などが含まれている。FcRnは, IgG の分解の半減 期, 血管外への輸送, 胎盤の通過などに関与している。IgG が胎盤を通過するのは, 新生児に免疫機能がなく, 生後 6-9 力月は母体由来の $\mathrm{IgG}$ 抗体によって保護されているためであ る。Fcレセプターと補体成分 $\mathrm{C} 1 \mathrm{q}$ の活性化により, 感染の発 病を抑えるような炎症反応のカスケードが引き起こされる。 これらの活性は $\mathrm{IgG}-\mathrm{Fc}$ 上の $N$ 型糖鎖に強く依存して抢り, 通常のポリクローナル $\operatorname{IgG}$ の中に存在する異なるグライコフ オームの間で変動がみられる(13-15)。逆に，FcRn の結合抒 
The IgG-Fc region is a homodimer comprised of covalent inter-heavy chain disulphide-bonded hinge regions and non-covalently paired $\mathrm{C}_{\mathrm{H}} 3$ domains; the $\mathrm{C}_{\mathrm{H}} 2$ domains are glycosylated through covalent attachment of an oligosaccharide at asparagine 297 (Asn-297). X-ray crystallographic analysis reveals a discreet structure for the oligosaccharide that forms multiple non-covalent interactions with the inner protein surface of the $\mathrm{C}_{\mathrm{H}} 2$ domain $(3,16,17)$. There is cumulative evidence that interaction sites on IgG-Fc for Fc $\gamma \mathrm{RI}, \mathrm{Fc} \gamma \mathrm{R} I, \mathrm{Fc} \gamma \mathrm{R}$ III and $\mathrm{C} 1 \mathrm{q}$ effector ligands are comprised principally of the protein moiety, however, generation of the interaction sites for these ligands is dependent on IgG-Fc protein/oligosaccharide interactions. Thus, effector mechanisms mediated through Fc $\gamma \mathrm{R} I$, Fc $\gamma \mathrm{R} I$ I, Fc $\gamma \mathrm{R}$ III and C1q are severely compromised or ablated for aglycosylated or deglycosylated forms of $\operatorname{IgG}(4,9-13)$.

\section{Glycoform profiles of normal serum derived IgG, in health and disease}

The oligosaccharides present in the IgG-Fc of normal polyclonal IgG, attached at Asn 297, are of the complex diantennary type and comprised of a core heptasaccharide with variable addition of fucose, galactose, bisecting $\mathrm{N}$-acetylglucosamine and sialic acid; sialylation is modest with $<10 \%$ of structures being monosialylated or disialylated $(4,17-20)$. The relative yields and structure of the neutral oligosaccharides released from normal IgG-Fc are shown in Figs. $2 \&$ 3, respectively. Each heavy chain may bear one of a total of 32 unique oligosaccharides and random pairing of heavy chain glycoforms could generate $>500$ glycoforms. Given the paucity of sialylation neutral oligosaccharides predominate but they alone allow for the generation of 128 unique glycoforms; the possible number of combinations $(16 \times 16)$ is divided by 2 to account for the symmetry of the molecule. A shorthand system of nomenclature for the oligosaccharides are G0 (zero galactose), $\mathrm{G} 1$ and $\mathrm{G} 2$ for oligosaccharides bearing one or two galactose residues, respectively, and G0F, G1F and G2F when fucose is present; when bisecting $\mathrm{N}$-acetylglucosamine is present a B is added, e.g. G0B, G0BF etc. The glycoform of the whole molecule reflects the oligosaccharides present on each heavy chain and may be represented as (G0/G0), (G0/G0F), (G0F/G0F), (G0/G1), (G0F/G1) etc. It is important to emphasise that these data were obtained by analysis of total polyclonal IgG that may be comprised of the product of thousands of individual plasma cell clones. Therefore, it was important to determine whether this oligosaccharide profile is characteristic for each individual
よびそれによる IgG の分解半減期の遅延は，抗体の糖鎖構造 に依存しない(3)。

$\mathrm{IgG}$ の $\mathrm{Fc}$ 領域は, ヒンジ領域における重鎖間ジスルフィ ド結合と $\mathrm{C}_{\mathrm{H}} 3$ ドメイン同士の非共有結合によって形成された ホモ2量体である。 $\mathrm{C}_{\mathrm{H}} 2$ ドメインはアスパラギン 297 番（Asn297）に糖鎖が共有結合で連結することによって修飾されてい る。X線結晶構造解析により糖鎖の立体構造が明らかにされて おり, 糖鎖が $\mathrm{C}_{\mathrm{H}} 2$ 領域間の内壁表面と多くの非共有結合によ り相互作用していることが示されている $(3,16,17)$ 。 IgG-Fc

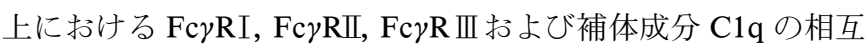
作用部位は, 主にタンパク質部分で構成されているという報 告が数多くなされているが，これらのリガンドの相互作用部 位は IgG-Fc 上のタンパク質と糖鎖の相互作用に依存して構築 されている。したがって，Fc $\gamma$ RI，Fc $\gamma$ RII, F $\gamma$ R III 抢よび補体 成分 $\mathrm{C} 1 \mathrm{q}$ が介するエフェクター機構は, $\operatorname{IgG} の$ 糖鎖が失われ ると顕著に減弱または消失してしまう(4,9-13)。

\section{C. 健常時および病態における血清由来 $\lg G$ の糖鎖プロファイ} ル

ポリクローナル $\operatorname{IgG}$ の $\mathrm{Fc}$ 領域のアスパラギン 297 番に結 合している糖鎖は通常，2 本鎖複合型糖鎖であり，5糖からな るコア構造に, フコース, ガラクトース, バイセクティング N-アセチルグルコサミン， シアル酸などが結合していたりし ていなかったりという多様な構造をしている。糖鎖の約 $10 \%$ 未満がシアリル化されて打り，モノシアリル化，ダイシアリ ル化糖鎖として存在している $(4,17-20)$ 。健常人の $\operatorname{IgG}-\mathrm{Fc}$ か ら遊離した中性糖鎖の相対量と構造をそれぞれ図 2 と図 3 に 示す。各重鎖には合計 32 種類のとり得る糖鎖構造の 1 つが発 現しており，重鎖の無作為な組み合わせにより $\mathrm{IgG}$ 分子とし て500 種類を越えるグライコフォームが生み出されることに なる。シアリル化の割合は少ないため，大部分が中性糖鎖と 考えても, $\operatorname{IgG}$ として 128 種類のグライコフォームが存在す る。これは中性糖鎖の組み合わせ $(16 \times 16)$ の数を, 分子の 対称性を考慮したうえで 2 で割った数である。糖鎖の略号々 して, ガラクトースを含まない糖鎖を G0，1 含むものを $\mathrm{G} 1 ， 2$ つ含むものを $\mathrm{G} 2$ とし, さらにフコースが存在する場 合, G0F, G1F, G2F と表す。またバイセクティングN-アセチ ルグルコサミンが結合している場合は B, を加えて G0B, $\mathrm{G} 0 \mathrm{BF}$ などと表記する。 IgG 分子全体としての糖鎖構造は, $(\mathrm{G} 0 / \mathrm{G} 0),(\mathrm{G} 0 / \mathrm{G} 0 \mathrm{~F}),(\mathrm{G} 0 \mathrm{~F} / \mathrm{G} 0 \mathrm{~F}),(\mathrm{G} 0 / \mathrm{G} 1),(\mathrm{G} 0 \mathrm{~F} / \mathrm{G} 1)$ とい うように各重鎖上の糖鎖を使って表すことができよう。こう したデータは全ポリクローナル $\mathrm{IgG}$ の分析により得られたも のであり，それらは莫大な種類のプラズマ細胞クローンの所 産であるかもしれないということを強調したい。それゆえ， 


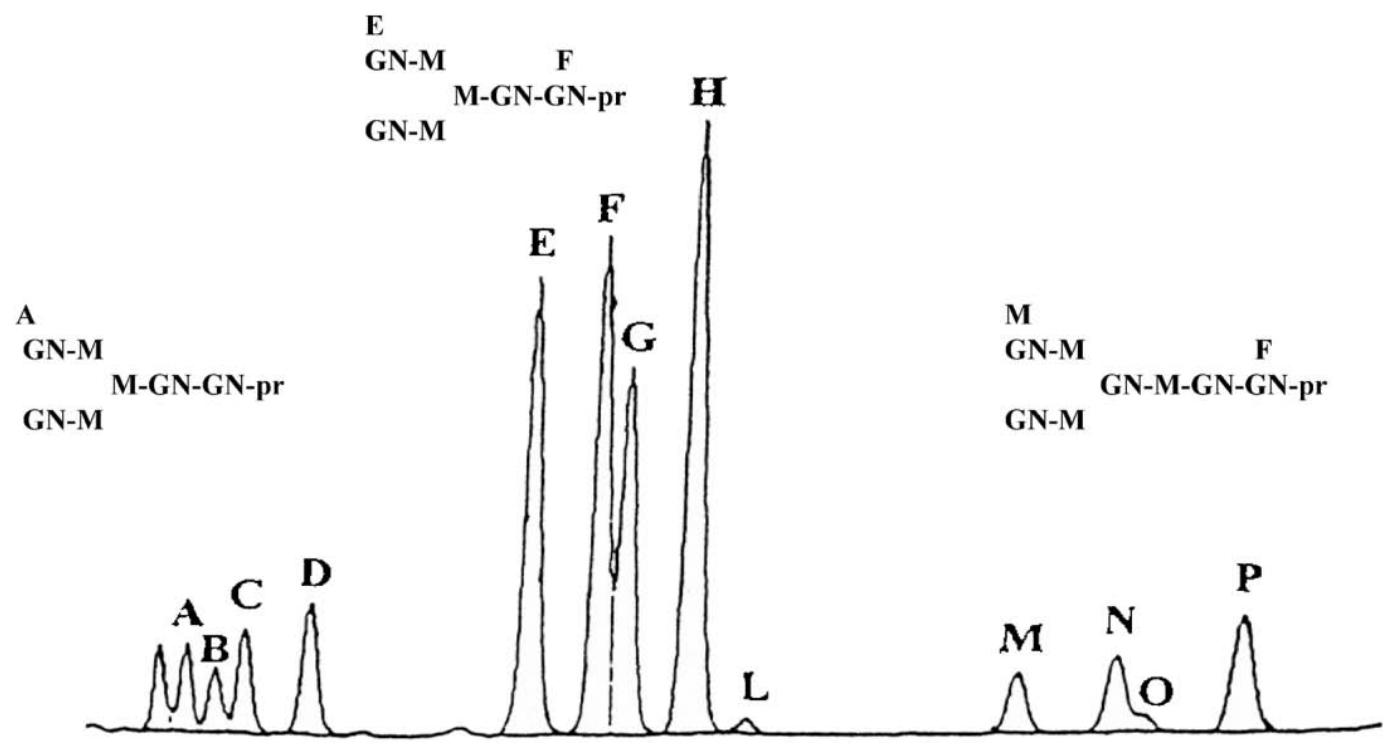

Fig. 2. An HPLC profile of the neutral complex diantennary oligosaccharide structures released from normal human IgG-Fc.

(A)<smiles>[14CH3][Mg][W]#N</smiles>

G0

(E)

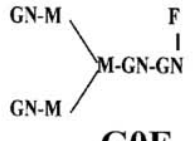

G0F

(I)

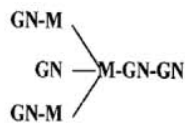

G0B
(B)

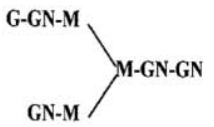

G1
(C)

(G)

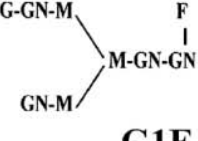

G1F
(J)

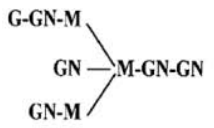

G1B
(K)<smiles>CCC(C)(C)[13CH3]</smiles>

G1B

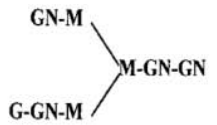

G1

(D)

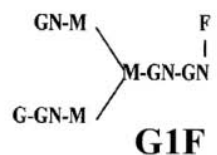

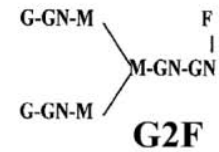

(M)

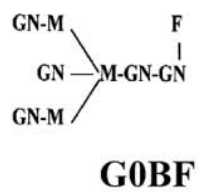

(N)

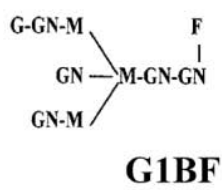

(0)

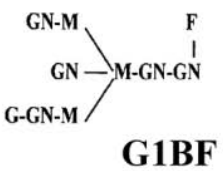

(L)

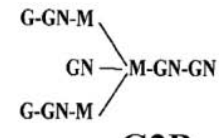

G2B

Fig. 3. Neutral oligosaccharides present in normal serum IgG-Fc

antibody population present or whether it represents the aggregate of thousands of individual clones each bearing a unique array of oligosaccharides.

This question was resolved by analysis of a panel of monoclonal IgG proteins, isolated from the sera of patients with IgG multiple myeloma (1); a cancer in which
こうした糖鎖プロファイルがそれぞれの抗体集団の特徵を反 映しているものであるのか，それともそれぞれユニークな一 群の糖鎖構造を発現している多種類のクローンの総計を反映 しているのかを決めることは重要である。

この疑問は, $\operatorname{IgG}$ 多発性骨髄腫（単一の $\operatorname{IgG}$ を産生する 
a single IgG producing plasma cell becomes neoplastic and secretes a paraprotein. This study showed that each IgG paraprotein yielded an individual IgG-Fc oligosaccharide profile and wide variations in the content of fucose, bisecting $\mathrm{N}$-acetylglucosamine and galactose were observed between paraproteins. In addition, subtle variations between the IgG subclasses were observed for the addition of galactose to $\alpha(1-3)$ or $\alpha(1-6)$ arms. There was a preference for addition to the $\alpha(1-6)$ arm for IgG1 and IgG4 and to the $\alpha(1-3)$ arm for IgG2; the arm preference for IgG3 paraproteins varied between allotype related sequences. These data suggest that a minor glycoform detected within normal polyclonal IgG-Fc may be the predominant glycoform present within a specific antibody population. This prediction appears to have been validated from analysis of glycopeptides released from $\operatorname{IgG}$ autoantibodies to platelet antigens (21).

The glycoform profile of normal polyclonal $\operatorname{IgG}$ is subject to variation with age, over the term of pregnancy and for a number of inflammatory conditions $(4,17-20,22,23)$. The major change reported is the extent of galactosylation, usually reported as the $\%[\mathrm{G} 0+\mathrm{G} 0 \mathrm{~F}+$ G0BF] oligosaccharides released. Thus, the levels of [G0 + $\mathrm{G} 0 \mathrm{~F}+\mathrm{G} 0 \mathrm{BF}]$ reported for the elderly exceeds that reported for adults between 20 and 50 years of age (22). The level of $[\mathrm{G} 0+\mathrm{G} 0 \mathrm{~F}+\mathrm{G} 0 \mathrm{BF}]$ decreases from the third trimester of pregnancy and increases again following parturition (23); it is tempting to associate the consequent increase in galactosylation with FcRn mediated passage of maternal IgG to the foetus, via the placenta and umbilical cord.

Increased levels of $[\mathrm{G} 0+\mathrm{G} 0 \mathrm{~F}+\mathrm{G} 0 \mathrm{BF}]$ are reported in a number of inflammatory diseases that have an autoimmune component, e.g. rheumatoid arthritis, vasculitis, coeliac disease etc (24-27). The initial finding of increased agalactosyl oligosaccharides in $\mathrm{IgG}$ isolated from the sera of patients with rheumatoid arthritis led to a proposal that $\mathrm{IgG}$ molecules devoid of galactose on both heavy chains may constitute "altered self" and be the autoantigen that provokes the production of the autoantibody rheumatoid factor $(24,25)$. Subsequent findings of elevated levels of agalactosylated IgG-Fc in other inflammatory diseases, not associated with the presence of rheumatoid factor, demonstrate that it does not equate to the aetiology of disease but may represent "acute phase reactants" that reflect inflammation and may contribute to an exacerbation of inflammation $(26,27)$.

We have observed the most extreme examples of hypogalactosylation for $\mathrm{IgG}$ isolated from the sera of patients with Wegner's granulomatosis or microscopic polyangiitis (26). These data were obtained for the total IgG-Fc oligosaccharides, not the autoantibodies, and sug-
プラズマ細胞が新生物化して異常タンパク質を分泌するよう になったがん）の患者の血清から単離した一連のモノクロー ナル IgG の糖鎖分析を行うことで解決された(1)。この研究に より，異常 $\operatorname{IgG}$ はそれぞれ異なる糖鎖発現パターンを示して いることが明らかとなった。異常タンパクの中で, フコー ス，バイセクティングの $\mathrm{N}-$ アセチルグルコサミン，ガラク トースの割合が幅広く変化していた。さらに IgG サブクラス の間で， $\alpha(1-3)$ または $\alpha(1-6)$ 枝に対するガラクトースの付 加にわずかながら違いが見られた。 IgG1 と IgG4 は（1-6）枝 に, IgG2 は（1-3）枝にガラクトースが付加されている傾向 が見られた。IgG3に関しては, アロタイプに関連したアミノ 酸配列によって，いずれの枝が優先されるかに違いが見られ た。これにより, 通常のポリクローナル $\mathrm{IgG}-\mathrm{Fc}$ のプロファイ ルに扔いて検出されるマイナーな糖鎖構造は, ある特別な抗 体の集団の中では主要なものであり得るということが示唆さ れた。この予想は血小板抗原に対する自己抗体から由来され た糖ペプチドの分析によっても確認されている(21)。

健常人のポリクローナル $\mathrm{IgG}$ の糖鎖構造プロファイルは 年齢, 妊娠, 多くの炎症疾患によって変化する $(4,17-20,22$, 23)。最も大きく変化するのはガラクトシル化の度合いであ り，通常は，遊離した糖鎖のうちの G0, G0F, G0BF の割合の 合計 $[\mathrm{G} 0+\mathrm{G} 0 \mathrm{~F}+\mathrm{G} 0 \mathrm{BF}](\%)$ で報告される。したがって, 高齢者の $[\mathrm{G} 0+\mathrm{G} 0 \mathrm{~F}+\mathrm{G} 0 \mathrm{BF}]$ レベルは，20〜 50 歳の成人に ついて報告されている值を超えている $(22)$ 。妊娠第 3 期に入 ると $[\mathrm{G} 0+\mathrm{G} 0 \mathrm{~F}+\mathrm{G} 0 \mathrm{BF}]$ レベルは減少し, 出産すると再び増 加する (23)。こうなると, IgGのガラクトシル化が結果的に 増大寸ることと, FcRn が胎盤や臍帯を介して母親の IgG を胎 児に移行することとの間に何か関連があると思わずにはいら れない。

$[\mathrm{G} 0+\mathrm{G} 0 \mathrm{~F}+\mathrm{G} 0 \mathrm{BF}]$ レベルが増加することは, 慢性関接 リウマチ，血管炎，セリアック病などの自己免疫性の因子を 伴う多くの炎症性疾患について報告されている(24-27)。IgG の非ガラクトシル化糖鎖の増大は慢性間接リウマチ患者の血 清から単離された IgGに扔いて初めて見出された。これによ り, 両重鎖からガラクトースが欠如した IgG は“変化した自 己”を構成して抢り，それが自己抗原として自己抗体である リウマチ因子の産生を促しているのかもしれないという仮説 が導かれた $(24,25)$ 。その後, リウマチ因子の存在と無関係な 他の炎症性疾患に扔いても非ガラクトシル化した $\mathrm{IgG}-\mathrm{Fc}$ の増 大が見出だされた。このことは, ガラクトースのない IgGは 病気の原因とは言えないが, 炎症を反映し, その増悪に寄与 するかもしれない“急性期の反応物”であるという可能性を 示している $(26,27)$ 。

我々はこれまでに, 低ガラクトシル化の最も極端な例と 
gests that some "factor(s)" are acting to modulate the glycosylation machinery of the Golgi apparatus in a majority of plasma cells.

\section{Glycoform profiles of recombinant IgG produced in non-human mammalian cells}

The advent of monoclonal antibodies, produced initially by mouse hybridomas, in vivo, and subsequently as recombinant proteins in Chinese hamster ovary $(\mathrm{CHO})$ or mouse NS0 and Sp2/0 cells, in vitro, led us, and others, to analyse their IgG-Fc glycoform profiles. In each case the dominant oligosaccharide present was G0F, with small amounts of G1F and G2F; also present were small quantities of non-fucosylated human type oligosaccharides (28). These cells do not add bisecting $\mathrm{N}$-acetylglucosamine residues. Thus, the predominant glycoforms produced are similar to the hypogalactosylated forms reported for IgGFc isolated from the sera of patients with inflammatory autoimmune diseases. In the absence of galactose residues the terminal sugar is $\mathrm{N}$-acetylglucosamine; a sugar residue that may be bound by the naturally occurring human lectins mannose binding ligand (MBL), present in blood, and the mannose receptor (MR), present on the surface of leucocytes and reticular endothelial cells (4). Binding to these lectins can result in activation of the complement cascade and/or internalisation, degradation, processing and possible antigen presentation. It should be emphasised that these lectins are pattern recognition receptors and may only be activated by specific arrays of the sugar residues. However, a recent example of clearance through the MR has been reported for the licensed IgG-Fc fusion protein Lenercept $(29,30)$. The production cell lines may also add oligosaccharides not reported for human $\operatorname{IgG}$ and/or oligosaccharides not known to be present in any human glycoprotein.

The paucity of galactosylation and sialylation of IgG-Fc may reflect its intimate integration within the protein structure with consequent limited access to glycosyltransferases. The balance between structure and accessibility is graphically illustrated for a panel of IgGFcs in which amino acid residues contributing to contacts with the oligosaccharide were replaced, sequentially, by alanine (31). In each case replacement of a single contact residue resulted in the production of hypergalactosylated and highly sialylated glycoforms. This again demonstrated that hypogalactosylation and pauci-sialylation are not due to deficits in the processing machinery of the Golgi ap-
して, ウェゲナー肉芽腫症あるいは微小多発性血管炎の患者 血清から単離した IgG を観察している(26)。これらのデータ は, 自己抗体ではなく, すべての IgG-Fc が発現している糖鎖 について得られたもので，“何らかの因子”が，大部分のプラ ズマ細胞のゴルジ装置に抢ける糖鎖生合成マシナリーに変調 作用を及ぼしていることを示唆している。

D. ヒト以外の哺乳細胞で産生したリコンビナント $\lg G$ の糖鎖 構造プロファイル

モノクローナル抗体の出現に導かれて, 私たちは, そし て他のグループも，それらの IgG-Fc の糖鎖構造の解析を実施 するようになった。モノクローナル抗体は当初はマウスの八 イブリドーマにより in vivo で産生されたが, その後, チャイ ニーズハムスター卵巣 $(\mathrm{CHO})$ 細胞やマウスの NS0 細胞ある いは $\mathrm{Sp} 2 / 0$ 細胞によりリコンビンナント体として作られるよ うになった。いずれの場合も，G0F が主な糖鎖であり，G1F および $\mathrm{G} 2$ 糖鎖は少なかった。またフコース残基が結合してい ないヒト型の糖鎖も少なかった $(28)$ 。これらの細胞はバイセ

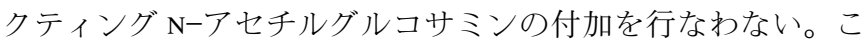
のように, 生産される主要な糖鎖は, 炎症性の自己免疫疾患

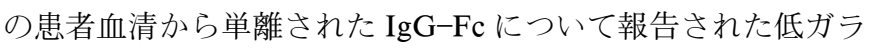
クトシル化型と類似していた。ガラクトース残基が欠如した

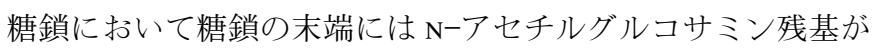

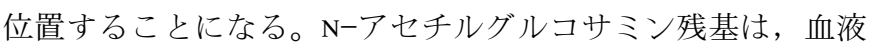
中に存在する天然のヒトレクチンであるマンノース結合レク チン (MBL) や白血球や細網内皮細胞の表面に存在するマン ノースレセプター（MR）に結合する可能性がある(4)。IgG がこれらのレクチンと結合すれば, 補体カスケードの活性化 や, 内部移行 · 分解 - 修飾 · 抗原提示が引き起こされ得る。 これらのレクチンはパターン認識レセプターであり, 糖残基 が特別な並び方をしている場合にの久活性化させ得るはずで ある。ところが最近，MRを介したクリアランスを利用した 例として, 認可された IgG-Fc 融合タンパク質である Lenercept が報告されている $(29,30)$ 。その産生細胞株はヒト IgG に おいて報告されていない糖鎖やヒトの糖タンパク質に存在が 知られていない糖鎖をも付加してしまうかもしれない。

$\mathrm{IgG}-\mathrm{Fc}$ のガラクトシル化やシアリル化がそしいことは, その構造がタンパク質の立体構造の中で緊密に構築されてい る結果，糖転移酵素の接近が制限されることを反映している のかもしれない。こうした構造の構築と接近しやすさのバラ ンス関係は, 糖鎖との接触に寄与するアミノ酸残基を順次ア

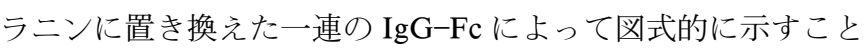
ができた $(31)$ 。いずれの場合も，1つの接触残基を置換するこ とて, 高ガラクトシル化と高度にシアリル化されたグライコ 
paratus.

\section{E. The impact of glycosylation on structure and stability}

The profound impact of aglycosylation on effector functions suggests a similarly substantial impact on structure; however, numerous parameters investigated failed to reveal structural change. Assignment of the chemical shifts in NMR for the histidine residues of IgG-Fc offered a sensitive probe for structural change as these residues are distributed throughout the IgG-Fc. A comparison of the NMR spectra of glycosylated and aglycosylated IgG-Fc revealed an altered environment for histidine 268 only (32). This histidine residue is present in the $\mathrm{C}_{\mathrm{H}} 2$ domain and is proximal to the lower hinge region. Subsequent studies employing comprehensive alanine replacements also suggested the hinge proximal region of the $\mathrm{C}_{\mathrm{H}} 2$ domain to be involved in $\mathrm{F} c \gamma \mathrm{R}$ and $\mathrm{C} 1 \mathrm{q}$ binding. Confirmation of these indirect assignments for the location of interaction site for $F c \gamma R$ binding was obtained with solution of the $\mathrm{x}$ ray crystal structure of an Fc $\gamma \mathrm{R}$ III/IgG-Fc complex (33).

The impact of glycoform on stability was determined by differential scanning micro-calorimetry (DSCM) of a panel of homogeneous glycoforms of IgG-Fc with progressive truncation of the oligosaccharide (34). Removal of terminal galactose residues did not impact on the melting temperature of either the $\mathrm{C}_{\mathrm{H}} 2$ or $\mathrm{C}_{\mathrm{H}} 3$ domains; however, subsequent removal of the $\mathrm{N}$-acetylglucosamine and the two arm mannose residues, generating a glycoform bearing only the $\mathrm{GlcNAc}_{2}$ Man trisaccharide, resulted in lowering of the melting temperature of the $\mathrm{C}_{\mathrm{H}} 2$ domain but not the $\mathrm{C}_{\mathrm{H}} 3$ domain. The thermodynamic parameters describing $\mathrm{C}_{\mathrm{H}} 2$ thermal denaturation of all IgG-Fc glycoforms was consistent with a cooperative unfolding. By comparison the unfolding of the $\mathrm{C}_{\mathrm{H}} 2$ domain of deglycosylated IgG1-Fc was non-cooperative, involving at least one intermediate. It was proposed that this intermediate is a partially unfolded $\mathrm{C}_{\mathrm{H}} 2$ domain pair possessing hinge proximal disordered/unfolded loops that may account for the compromised functional activities of deglycosylated IgG and IgG-Fc $(34,35)$.

The (GlcNAc) ${ }_{2} \mathrm{Man}$ trisaccharide was thus shown to confer a degree of order/structural stability on the $\mathrm{C}_{\mathrm{H}} 2$ domain and the generation of lower hinge conformers compatible with $\mathrm{Fc} \gamma \mathrm{R}$ and $\mathrm{C} 1$ binding and activation. These data are consistent with $\mathrm{x}$-ray crystal data obtained for the same truncated IgG-Fc glycoforms that showed progressive increases in the temperature factors for the
フォームがもたらされた。このことはまた， IgG-Fc の低ガラ クトシル化や乏しいシアリル化の原因が，ゴルジの装置の糖 鎖プロセッシングマシーナリーの不全によるものではないこ とを示すものとなった。

\section{E. 構造および安定性への糖鎖修飾の影響}

糖鎖の欠損がエフェクター機能にもたらす重要な影響が 大きいことを考えると，IgGの構造に対しても同じように甚 大な影響が及んでいることが示唆される。しかしながら，こ れまで多くのパラメーターについて探査がなされたにもかか わらず，構造変化を明らかにすることはできなかった。ヒス チジン残基は $\mathrm{IgG}-\mathrm{Fc}$ 全体に分布していることから，それらの NMR 化学シフトを帰属することにより，構造変化を鋭敏に捕 えるプローブがもたらされた。ガラクトース残基の有無につ いて IgG-Fe の NMR スペクトルを比較したところ，ヒスチジ ン 268 番目のみについて環境の違いが明らかになった。この ヒスチジン残基は $\mathrm{C}_{\mathrm{H}} 2$ ドメインに存在し，ヒンジの下流部分 に近接している。その後の広範なアラニン置換を用いた研究 により， $\mathrm{C}_{\mathrm{H}} 2$ ドメインのヒンジに近接した領域が $\mathrm{F} c \gamma \mathrm{R}$ と C1q の結合部位に含まれることも示唆された。こうした間接 的なやり方で定められた $\mathrm{F} \gamma \mathrm{R}$ の相互作用部位の位置は,

$\mathrm{F} c \gamma \mathrm{R}$ III/IgG-Fc 複合体の結晶構造が解かれることにより確認 されることとなった (33)。

糖鎖構造が分子の安定性に及ぼす影響は，糖鎖を段階的 に切除することによって得られた均一なグライコフォームか らなる一連の $\mathrm{IgG}-\mathrm{Fc}$ を用いた示差走査カロリメトリー （DSMC）を用いて明らかにされた（34）。末端のガラクトース 残基を除去しても, $\mathrm{C}_{\mathrm{H}} 2$ と $\mathrm{C}_{\mathrm{H}} 3$ のいずれの変性温度にも変化 を与えなかった。しかしながら引き続いて N-アセチルグルコ サミン残基，両枝のマンノース残基を取り除いた $\mathrm{GlcNAc}_{2}$ $\operatorname{Man} の 3$ 糖構造にすると, $\mathrm{C}_{\mathrm{H}} 3$ の変性温度は変化しないが, $\mathrm{C}_{\mathrm{H}} 2$ の変性温度が低下した。全ての $\mathrm{IgG}-\mathrm{Fc}$ のグライコフォー ムに打いて， $\mathrm{C}_{\mathrm{H}} 2$ ドメインの熱変性を記述する熱力学的パラ メーターは，協同的なアンフォールディングを示すことで一 致していた。それに比して，糖鎖を除去した $\mathrm{IgG}-\mathrm{Fc}$ の $\mathrm{C}_{\mathrm{H}} 2$ ドメインのアンフォールディングは非協同的であり，すくな くとも中間体を 1 つ含んでいた。この中間体はヒンジ近傍に 無秩序なループ構造をもった部分的に変性した $\mathrm{C}_{\mathrm{H}} 2$ ドメイン ペアにあたり，これらのループの構造が崩れていることが糖 鎖を除去した IgG や IgG-Fcに扔いて活性が損なわれている ことの原因であるのかもしれない $(34,35) 。$

このように $\mathrm{GlcNAc}_{2} \mathrm{Man}$ の 3 糖構造は, $\mathrm{C}_{\mathrm{H}} 2$ ドメインの 構造的な安定性と秩序をもたらし, F $\gamma$ R と $\mathrm{C} 1$ の結合や活性 化に適するヒンジ下流部分のコンフォメーションの形成に寄 
$\mathrm{C}_{\mathrm{H}} 2$ domain, as evidence of progressive structural disorder for the truncated glycoforms (16). Interestingly, in this study all attempt to obtain a crystal form of deglycosylated IgG-Fc failed. This may be indicative of the structural destabilisation that results from complete removal of oligosaccharides. Truncation of the sugar residues results in the mutual approach of $\mathrm{C}_{\mathrm{H}} 2$ domains with the generation of a "closed" conformation; in contrast to the "open" conformation observed for the fully galactosylated IgG-Fc (16). A truncated glycoform bearing only a fucosylated primary GlcNAc was shown not to bind soluble recombinant $\mathrm{Fc} \gamma \mathrm{R} \mathbb{\mathrm { II }}$ a and NMR studies indicated conformational alterations of the lower hinge region that contributes to $\mathrm{Fc} \gamma \mathrm{R}$ binding sites (36).

The effectiveness of recombinant monoclonal antibody (rMAb) in oncology depends on sensitizing target cells for subsequent killing by the mechanisms of antibody dependent cellular cytotoxicity (ADCC), complement dependent cytotoxicity (CDC) and/or the induction of apoptosis. It is unequivocally established that ADCC and CDC are dependent on appropriate glycosylation of the rMAb (4,12-16) whilst induction of apoptosis may only require cross-linking of cell surface antigens. Glycosylation has been a focus of interest for the biopharmaceutical industry for the past several years and cell lines have been engineered in efforts to optimise antibody products for ADCC and CDC by the differential addition of fucose, galactose, bisecting $\mathrm{N}$-acetylglucosamine and sialic acid. These studies have shown that the affinity of Ig$\mathrm{G}-\mathrm{Fc}$ for $\mathrm{Fc} \gamma \mathrm{R} I \mathrm{II}$ a, expressed on natural killer (NK) cells, is significantly increased for IgG-Fc glycoforms lacking $\alpha(1-6)$ fucose residues, with a consequent dramatic increase in NK cell mediated ADCC (13-15).

\section{F. Glycosylation of IgG-Fab}

It is established that $\sim 30 \%$ of polyclonal human IgG molecules bear $N$-linked oligosaccharides within the IgG-Fab region, in addition to the conserved glycosylation site at Asn 297 in the IgG-Fc (4,10,36-39). When present they are attached within the variable regions of the kappa $(\mathrm{V} \kappa)$, lambda $(\mathrm{V} \lambda)$ or heavy $(\mathrm{VH})$ chains; sometimes both. In the immunoglobulin sequence database $\sim 20 \%$ of $\operatorname{IgG}$ variable regions have $N$-linked glycosylation consensus sequences (Asn-X-Thr/Ser; where X can be any amino acid except proline). Interestingly, these consensus sequences are mostly not germline encoded but result from somatic
与していることが示された。これらのデータは, 同じく切断 された糖鎖構造を持つ一連の IgG-Fc が，糖鎖の短鎖化に伴っ て $\mathrm{C}_{\mathrm{H}} 2$ ドメインの温度因子が構造の乱れの証左として増加し ていくというX 線結晶データとも矛盾していない $(16)$ 。興味 深いことに, この研究では, 糖鎖を除去した IgG-Fc の結晶は 得られなかった。これは，糖鎖を完全に除去することにより， $\mathrm{IgG}-\mathrm{Fc}$ の構造が不安定化することを意味しているのかもしれ ない。糖鎖を短鎖化することにより $\mathrm{C}_{\mathrm{H}} 2$ ドメインは互いに接 近し，“閉じた”コンフォメーションを形成する。このことは, 完全にガラクトースが結合した IgG-Fc が “開いた” コンフォ メーションを形成することと対照的である(16)。また，フ コースと $\mathrm{N}$ アアセチルグルコサミンの 2 糖のみに糖鎖構造を短 鎖化すると可溶型のリコンビナント F c $\gamma \mathrm{R}$ III $\mathrm{a}$ に結合できなく なることが示されて抢り, NMR 研究の結果, Fc $\gamma \mathrm{R}$ の結合部 位であるヒンジ下流領域にコンフォメーション変化が引き起 こされることが明らかとなっている(36)。

腫瘍学の分野におけるリコンビナントモノクローナル抗 体の有効性は，標的細胞を感作し，それに引き続いて抗体依 存性細胞障害 (ADCC), 補体依存性障害 $(\mathrm{CDC})$, アポトー シスの誘導という機構でそれらを殺傷することに依存してい る。アポトーシスの誘導には細胞表面の抗原の架橋のみが招 そらく必要であるのに対して, ADCC とCDC はリコンビナ ントモノクローナル抗体の適切な糖鎖修飾に依存していると いうことは異論を差し挟む余地が無い。過去数年間, 糖鎖修 飾はバイオ医薬品産業の興味の的であり, 細胞株のエンジニ アリングによってフコース, ガラクトース, バイセクティン グ $\mathrm{N}$-アセチルグルコサミン, シアル酸の付加を変化させ, 生 産物としての抗体の ADCC と CDC を最適化しようという努 力がはらわ机ている。こうした研究により, ナチュラルキ ラー（NK）細胞上に発現されている $\mathrm{F} c \gamma \mathrm{R} I I \mathrm{a}$ に対する $\mathrm{IgG}-$ $\mathrm{Fc}$ の親和性が， $\alpha 1,6$ フコース残基を欠落した $\mathrm{IgG}-\mathrm{Fc} に$ に扔い て有意に増大して抢り，その結果，NK 細胞を介した ADCC 活性が劇的に向上することが示されている(13-15)。

\section{F. IgG-Fab の糖鎖修飾}

ポリクローナルヒト $\mathrm{IgG}$ の約 $30 \%$ は， Fc 上のアスパラ ギン 297 番に保存された糖鎖結合部位に加えて, Fab 領域に 糖鎖を発現しているということが確立されている $(4,10,36-$ 39)。そうした糖鎖は， $\kappa$ 鎖， $\lambda$ 鎖，あるいは重鎖の可変領域 (それぞれ， $\mathrm{V}_{\kappa}, \mathrm{V}_{\lambda}, \mathrm{V}_{\mathrm{H}}$ ) の一方，ときには両方に結合してい る。免疫グロブリンの配列データベースによれば, $\operatorname{IgG} の$ 可 変領域の $20 \%$ には， $N$ 型糖鎖結合のコンセンサス配列（Asn$\mathrm{X}-\mathrm{Thr} / \mathrm{Ser}, \mathrm{X}$ はプロリン以外のアミン酸）が存在している。 興味深いことに, これらのコンセンサス配列は多くの場合, 
mutation - suggestive of positive selection for improved antigen binding. Analysis of polyclonal human IgG-Fab reveals the presence of diantennary oligosaccharides that are extensively galactosylated and substantially sialylated, in contrast to the oligosaccharides released from IgG-Fc $(4,10,36-39)$. This pattern was maintained for IgG-Fab prepared from hypogalactosylated $\mathrm{IgG}$ isolated from the sera of patients with Wegner's granulomatosis or microscopic polyangiitis (38). Thus, factors within the local environment of IgG producing plasma cells, in vivo, influence the efficacy of glyco-processing of IgG-Fc but not IgG-Fab during passage through the Golgi apparatus. The functional significance for IgG-Fab glycosylation of polyclonal IgG has not been fully evaluated but data emerging for monoclonal antibodies suggests that $\mathrm{V} \kappa, \mathrm{V} \lambda$ or VH glycosylation can have a neutral, positive or negative influence on antigen binding $(4,10)$.

It is generally observed that the oligosaccharide present in glycoproteins contributes to solubility and stability; the influence of glycosylation on the thermal stability of human IgG1-Fc was demonstrated in a DSMC study $(16,34,35)$. It is possible that IgG-Fab glycosylation may similarly be beneficial, particularly when formulating IgG therapeutics at concentrations of $100-150 \mathrm{mg} / \mathrm{ml}$. Such high concentration formulations allow the development of self-administration protocols and can reduce dosing intervals, resulting in reduced costs of treatment. Controlling glycoform fidelity at two sites offers a further challenge to the biopharmaceutical industry.

The licensed antibody therapeutic Erbitux (Cetuximab), bears an $N$-linked oligosaccharide at Asn 88 of the $\mathrm{VH}$ region; interestingly there is also a glycosylation motif at Asn 41 of the VL but it is not occupied (40). Analysis of the IgG-Fc and IgG-Fab oligosaccharides of Erbitux, produced from $\mathrm{Sp} 2 / 0$ cells, reveal highly significant differences in composition. Whilst the IgG-Fc oligosaccharides are typical, i.e. comprised predominantly of diantennary G0F oligosaccharides, the IgG-Fab oligosaccharides are extremely heterogeneous and include complex diantennary, triantennary and hybrid oligosaccharides; non-human oligosaccharides were also present, e.g. galactose in $\alpha(1-3)$ linkage to galactose and $\mathrm{N}$-glycylneuraminic acid residues.

A recent study reported that of 76 patients treated with Erbitux 25 had hypersensitivity reactions to the drug and this was shown to be due to the presence of $\operatorname{IgE}$ antigal $\alpha(1-3)$ gal antibodies. Interestingly, environmental factors appeared to influence the development of IgE antigal $\alpha(1-3)$ gal responses and such antibodies were detected in pre-treatment samples from 17 of the patients (41). The incidence varied significantly between treatment centres and may be linked to differences in predominant infectious
生殖細胞にコードされたものではなく，体細胞変異の結果と して生じたものである。このことは抗原結合性の向上により 正の選択を受けたことを示唆している。ポリクローナルヒト $\operatorname{IgG}$ の Fab の分析の結果, そこに発現している糖鎖は, Fc か ら遊離した糖鎖とは異なり，高度にガラクトシル化され，実 質的にシアリル化がされた 2 本鎖糖鎖であることが明らかと なっている $(4,10,36-39)$ 。この様式は, ウェゲナー肉芽腫症, 微小多発性血管炎の患者血清から単離された低ガラクトシル 化 $\mathrm{IgG}$ 由来の Fab においても保存されていた (38)。したがっ て，in vivoにおいて $\operatorname{IgG}$ を産生するプラズマ細胞の局所的な 環境因子は，ゴルジの装置を経由する移行過程に扔いて，IgG の Fab でなく Fc の糖鎖プロセシングの効果にの久影響を及ぼ すということになる。ポリクローナル IgG の Fab 上の糖鎖修 飾の機能上の意義は十分に明らかにされているわけではない が，モノクローナル抗体について得られたデータは， $\mathrm{V}_{\kappa}, \mathrm{V}_{\lambda}$ あるいは $\mathrm{V}_{\mathrm{H}}$ に抢ける糖鎖修飾が，抗原結合に対して正負いず れの影響も与え得る, あるいは影響しない場合もある, とい うことを示している $(4,10)$ 。

糖タンパク質の糖鎖は溶解性と安定性に寄与しているこ とが一般的に認められている。ヒト IgG1-Fc の熱安定性に対 する糖鎖修飾の影響は，DSMCによる研究で実証された $(16,34,35)$ 。IgG-Fab に発現している糖鎖も同様な効果がある かもしれない。特に IgG 治療薬を 100-150 m $/ \mathrm{ml}$ といった濃 度で製造する際にこのことは有用であろう。そのような高濃 度の調合を行なうことができれば，自己投与プロトコールを 開発することが可能となり，投薬間隔をあけることができ る。これにより，結果的に治療のコストを減ずることになる。 $2 つ の$ 部位の糖鎖構造を厳密に制御することは, バイオ医薬品 産業にとって更なる挑戦的課題である。

認可された治療抗体 Erbitux（Cetuximab）は $\mathrm{V}_{\mathrm{H}}$ 領域の アスパラギン 88 番に $N$ 型糖鎖が結合している。面白いことに, $\mathrm{V}_{\mathrm{L}}$ 領域のアスパラギン 41 番にも糖鎖結合モチーフが存在す るが，そこには糖鎖は結合していない $(40) 。 \mathrm{Sp} 2 / 0$ 細胞によ り産生された Erbitux の Fc 抢よび Fab 部分の糖鎖の発現プロ ファイルは，著しく異なっていた。 IgG-Fc 上の糖鎖は，主に 2 本鎖 $\mathrm{G} 0 \mathrm{~F}$ 糖鎖から構成されている典型的な発現パターンを 示していたが， IgG-Fab 上の糖鎖のパターンは極端な不均一 性を示して扔り，2 本鎖，3本鎖の複合型糖鎖や混成型糖鎖か ら構成されていた。またガラクトースにガラクトースが $\alpha 1,3$ 結合した $(\alpha 1,3$ ガラビオース $)$ 構造や $\mathrm{N}$-グリコリルノイラミ ン酸残基を有する糖鎖などのヒト型でない糖鎖も存在してい た。

最近の研究では, Erbitux 投与された 76 人の患者中 25 人 が薬に対して過敏症を示したことが報告されていうる。これ 
agents present in local environments.

A detailed analysis of the glycoforms of a humanised IgG rMAb, also expressed in $\mathrm{Sp} 2 / 0$ cells, bearing oligosaccharides at Asn 56 of the $\mathrm{VH}$ and Asn 297 reveals the expected IgG-Fc profile of predominantly G0F oligosaccharides; however, eleven oligosaccharides were released from the IgG-Fab, including diantennary and triantennary oligosaccharides bearing gal $\alpha(1-3)$ gal, Nglycylneuraminic acid and $\mathrm{N}$-acetyl galactosamine residues (42). The consistent observation of higher levels of galactosylation and sialylation for IgG-Fab $\mathrm{N}$-linked oligosaccharides, in comparison to IgG-Fc, is thought to reflect increased exposure and/or accessibility. In view of these experiences it would seem that the perceived virtues of the NS0 and Sp $2 / 0$ cells might best be pursued by engineering to inactivate the gal $\alpha(1-3)$ and $\mathrm{N}$-glycylneuraminic acid transferases.

The double challenge to produce rMAbs having appropriately glycosylated IgG-Fc and IgG-Fab has led to some companies engineering out $\mathrm{V}_{\mathrm{H}}$ or $\mathrm{V}_{\mathrm{L}}$ glycosylation motifs when present in candidate rMAbs (43); however, present reports suggest that $\mathrm{CHO}$ cells can glycosylate $\mathrm{VH}$ and/or VL motifs in a similar manner to that observed for normal polyclonal IgG (44).

\section{G. Conclusions and next generation antibody therapeu- tics}

The dramatic increase in NK cell mediated ADCC reported for non-fucosylated Rituxan and Herceptin, in vitro, suggests that they may be similarly efficacious in vivo and offer significant clinical advantage (13-15). These fucosylated products are established in the clinic and are unlikely to be re-derivatised in the non-fucosylated form; however, new anti-CD20 and EGFR (epidermal growth factor receptor) are under development in the nonfucosylated format.

Initially the observed heterogeneity of $\operatorname{IgG}$ antibody glycoforms provided a challenge both for an understanding of its significance and for the manufacture of
は抗 $\alpha 1,3$ ガラビオース抗体である IgE の存在が原因であるこ とが示されている。興味深いことに, 抗 $\alpha 1,3$ ガラビオース $\operatorname{IgE}$ の応答に影響を与える環境因子が存在するらしく，その ような抗体は 17 人の患者からの治療前の試料にも検出されて いた (41)。過敏症の発生率は治療センターの間で異なってお り,このことは局所的な環境に存在する主要な感染病原体の 違いに関係しているかもしれない。

$\mathrm{Sp} 2 / 0$ 細胞により産生されたヒト化リコンビナントモノ クローナル $\mathrm{IgG}$ の詳細な糖鎖構造解析により， $\mathrm{V}_{\mathrm{H}}$ ドメインの アスパラギン 56 番とアスパラギン 297 番に糖鎖が付加してお り, Fc の糖鎖構造は予想通り G0F が主要な成分であることが 明らかとなった。しかしながら，Fab からは， $\alpha 1,3$ ガラビ オース, $\mathrm{N}$ ーグリコリルノイラミン酸, $\mathrm{N}$-アセチルガラクトサ ミン残基が結合した 2,3 本鎖構造を含む 11 種類の糖鎖が遊 離された $(42)$ 。これと呼応して本抗体の $\mathrm{Fab} の ~ N$ 型糖鎖は $\mathrm{Fc}$ の糖鎖と比べてガラクトシル化とシアリル化を高度にうけて いることがみとめられたが，これは Fab の糖鎖は露出度が高 く酵素の接近が起こりやすいことを反映していると考えられ る。以上の点を踏まえると，これまでに認識されているNS0 細胞や $\mathrm{Sp} 2 / 0$ 細胞の長所は， $\alpha 1,3$ ガラクトース転移酵素や $\mathrm{N}-$ グリコリルノイラミン酸を転移する酵素を不活性化する改変 を施すことによって一層磨かれるであろうと思われる。

$\mathrm{Fc}$ と $\mathrm{Fab}$ の両方が適切な糖鎖修飾をうけたリコンビナン トモノクローナル $\operatorname{IgG}$ を生産することは二重のハードルとな るため, いくつかの会社では, 候補となるリコンビナントモ ノクローナル抗体の $\mathrm{V}_{\mathrm{H}}$ あるいは $\mathrm{V}_{\mathrm{L}}$ ドメインに糖鎖結合モ チーフがあった場合に，それらを改変して無くしてしまうよ うにしている(43)。しかしながら，目下の報告では， $\mathrm{CHO}$ 細 胞が正常なポリクローナル $\mathrm{IgG}$ と同様な糖鎖構造で $\mathrm{V}_{\mathrm{H}}, \mathrm{V}_{\mathrm{L}}$ ドメインのモチーフを修飾することが可能であることが示唆 されている(44)。

\section{G. 結論および次世代の抗体治療}

フコース残基が欠失した Rituxan 抢よび Herceptin の NK 細胞を介した ADCC 活性が in vitro で劇的に向上することが 報告されており，そのことから，これらの抗体は生体内でも 同様な効果を有し，臨床的に甚だ有益であると考えられてい る(13-15)。これらのフコシル化体は製品として臨床上でも確 立されたものとなって抢り，非フコシル化体を作り直すとい うわけにはいきそうにない。しかしながら，新規な抗 CD20 抗体抢よび抗 EGFR（上皮成長因子レセプター）抗体は非フ コシル化体としての開発が進んでいる。

$\mathrm{IgG}$ 抗体に見出された糖鎖構造の不均一性は, 当初は, その意義を理解すること, そして天然の糖鎖構造を持つ抗体 
natural antibody glycoform products. Significant progress has been made both in understanding of differential functional activities of IgG glycoforms and in applying cell and protein engineering to optimise the production of individual and/or homogeneous glycoforms. Importantly, rapid and sensitive analytical protocols have been developed that allow for the glycoform profile to be a criterion applied to clonal selection at an early stage in the development of antibodies for new targets.

I trust that Prof. Takahashi derives great satisfaction from seeing how her pioneering studies and their continuous development have contributed to glycoscience. It is a privilege for me to be invited to record my appreciation.
を作り出すことが大きな課題であった。その後の重要な進展 により，IgGの糖鎖構造が異なる機能的活性を持つことに関 する理解が進み，また，それぞれの糖鎖構造を発現したり， あるいは均一な糖鎖構造を有する $\mathrm{IgG}$ の生産を最適化するた めに細胞工学やタンパク質工学を応用することも進歩を遂げ てきた。重要なことは, 新しい標的に対する抗体の開発の初 期段階におけるクローンの選択に際して基準となる糖鎖プロ ファイルを提供することができる迅速かつ敏感な分析プロト コールが開発されていることである。

最後に, ご自身の先駆的な研究とそのたゆま好発展が糖 鎖科学に貢献したことに，高橋教授が大いに満足されている ことを筆者は確信しています。ここに謝意を記すことができ ることを名誉に思います。

(名古屋市立大学大学院薬学研究科 加藤晃一訳)

\section{References}

1. Takahashi, N., Ishii, I., Ishihara, H., Mori, M., Tejima, S., Jefferis, R., Endo, S., and Arata, Y. (1987) Biochemistry, 26, $1137-1144$

2. Woof, J. M., and Burton, D. R. (2004) Nat Rev Immunol. 4, 89-99.

3. Nezlin, R., and Ghetie, V. (2004) Adv Immunol. 82, 155-215

4. Jefferis, R. (2007) Expert Opin Biol Ther. 7, 1401-1413

5. Carter, P. J. (2006) Nat Rev Immunol. 6, 343-357

6. Reichert, J. M., and Valge-Archer, V. E. (2007) Nat Rev Drug Discov. 6, 349-356

7. Moutel, S., and Perez, F. (2008) Biotechnol J. 3, 298-300

8. Nimmerjahn, F., and Ravetch, J. (2008) Nat Rev Immunol. 8, 34-47

9. van Sorge, N. M., van der Pol, W. L., and van de Winkel, J. G. (2003) Tissue Antigens. 61, 189-202

10. Jefferis, R. (2005) Biotechnology Progress. 21, 11-16

11. Sinclair, A. M., and Elliott, S. J. (2005) Pharm Sci. 94, 626-1635

12. Shields, R. L., Lai, J., Keck, R., O’Connell, L. Y., Hong, K., Mengm Y. G., Weikert, S. H., and Presta, L. G. (2002) J. Biol Chem. 277, 26733-26740

13. Shinkawa, T., Nakamura, K., Yamane, N., Shoji-Hosaka, E., Kanda, Y., Sakurada, M., Uchida, K., Anazawa, H., Satoh, M., Yamasaki, M., Hanai, N., and Shitara, K. (2003) J Biol Chem. 278, 3466-3473

14. Niwa, R., Natsumem, A., Ueharam, A., Wakitanim, M., Iidam, S., Uchidam, K., Satoh, M., and Shitara, K. (2005) J Immunol Methods. 306, 151-60

15. Ferrara, C., Brunker, P., Suter, T., Moser, S., Puntener, U., and Umana, P. (2006) Biotechnol Bioeng. 93, 851-61

16. Krapp, S., Mimura, Y., Jefferis, R., Huber, R., and Sondermann, P. (2003) J. Mol. Biol. 325, 979-989

17. Deisenhofer, J. (1981) Biochemistry 20, 2361-2370

18. Arnold, J. N., Wormald, M. R., Sim, R. B., Rudd, P. M., and Dwek, R. A. (2007) Annu Rev Immunol. 25, 21-50

19. Mizuochi, T., Taniguchi, T., Shimizu, A., and Kobata, A. (1982) J. Immunol. 129, 2016-2020

20. Routier, F. H., Hounsell, E.F., Rudd, P. M., Takahashi, N., Bond, A., Hay, F. C., Alavi, A., Axford, J. S., and Jefferis, R. (1998) J Immunol Methods 213, 13-30

21. Wuhrer, M., Porcelijn, L., Kapur, R., Koeleman, C. A., Deelder, A. M., de Haas, M., and Vidarsson, G. (2008) J Proteome Res Oct 23. [Epub ahead of print]

22. Yamada, E., Tsukamoto, Y., Sasaki, R., Yagyu, K., and Takahashi, N. (1997) Glycoconj J. 14, 401-405

23. Kibe, T., Fujimoto, S., Ishida, C., Togari, H., Wada, Y., Okada, S., Nakagawa, H., Tsukamoto, Y., Kawamura, Y., and Takahashi, N (1996) Clin Biochem Nutr 21, 57-63

24. Parekh, R. B., Dwek, R. A., Sutton, B. J., Fernandes, D. L., Leung, A., Stanworth, D., Rademacher, T. W., Mizuochi, T., Taniguchi, T., Matsuta, K., Takeuchi, F., Nagano, Y., Miyamoto, T., and Kobata, A. (1985) Nature. 316, $452-457$

25. Axford, J. S., Cunnane, G., Fitzgerald, O., Bresnihan, B., and Frears, E. R. (2003) J. Rheumatol. 12, $2540-2546$

26. Holland, M., Takada, K., Okumoto, T., Takahashi, N., Kato, K., Adu, D., Ben-Smith, A., Harper, L., Savage, C. O. S., and Jefferis, R. (2002). Clin. exp. Immunol. 29, 183-190

27. Cremata, J. A., Sorell, L., Montesino, R., Mata, M., Cabrera, G., Galvan, J. A., Garcia, G., Valdes, R., and Garrote, J. A. 2003 Clin. Exp. Immunol. 133, 422-9

28. Lund, J., Takahashi, N., Nakagawa, H., Bentley, T., Hindley, S., Tyler, R., Goodall, M., and Jefferis, R. (1993) Molec. Immunol. 30, 741-748 
29. Jones, A. J., Papac, D. I., Chin, E. H., Keck, R., Baughman, S. A., Lin, Y. S., Kneer, J., and Battersby, J.E. (2007) Glycobiology. 17, 529-40

30. Keck, R., Nayak, N., Lerner, L., Raju, S., Ma, S., Schreitmueller, T., Chamow, S., Moorhouse, K., Kotts, C., and Jones A. (2008) Biologicals. 36, 49-60

31. Lund, J., Takahashi, N., Pound, J., Goodall, M., and Jefferis, R. (1996) J.Immunol. 157, 4963-4969

32. Lund, J., Tanaka, T., Takahashi, N., Sarmay, G., Arata, Y. and Jefferis, R. (1990) Mol. Immunol. 27, $1145-1154$

33. Sondermann, P., Huber, R., Oosthuizen, V., and Jacob, U. (2000) Nature. 406 (6793), 267-73

34. Mimura, Y., Church, S., Ghirlando, R,. Dong, S., Goodall, M., Lund, J., and Jefferis, R. (2000) Molec Immunol. 37, 697-706

35. Mimura, Y., Sondermann, P., Ghirlando, R., Lund, J., Young, S. P., Goodall, M., and Jefferis, R. (2001). J.Biol.Chem. 276, 45539-45547

36. Yamaguchi, Y., Nishimura, M., Nagano, M., Yagi, H., Sasakawa, H., Uchida, K., Shitara, K., and Kato, K. (2006) Biochim. Biophys. Acta. 1760, 693-700

37. Youings, A., Chang, S. C., Dwek, R. A., and Scragg, I. G. (1996) Biochem J. 314, 621-630

38. Holland, M., Yagi, H., Takahashi, N., Kato, K., Savage, C. O. S., Goodall, D. M., and Jefferis, R. (2006) Biochim Biophys Acta. 1760, 669-77

39. Mimura, Y., Ashton, P. R., Takahashi, N., Harvey, D. J., and Jefferis, R. (2007) J Immunol Methods. 326, 116-126

40. Qian, J., Liu, T., Yang, L., Daus, A., Crowley, R., and Zhou, Q. (2007) Anal.Biochem. 364, 8-18

41. Chung, C. H., Chung, C. H., Mirakhur, B., Chan, E., Le, Q. T., Berlin, J., Morse, M., Murphy, B. A., Satinover, S. M., Hosen, J., Mauro, D., Slebos, R. J., Zhou, Q., Gold, D., Hatley, T., Hicklin, D. J., and Platts-Mills, T. A. (2008). N Engl J Med. 358, 1109-1117

42. Huang, L., Biolosi, S., Bales, K. R., and Kuchibhotla, U. (2006). Anal Biochem. 349, 197-207

43. Carter, P., Presta, L., Gorman, C. M., Ridgway, J. B., Henner, D., Wong, W. L., Rowland, A. M., Kotts, C., Carver, M. E., and Shepard, H. M. (1992) Proc Natl Acad Sci USA. 89, 4285-4289

44. Lim, A., Reed-Bogan, A., and Harmon, B. J. (2008) Anal Biochem. 375, 163-172

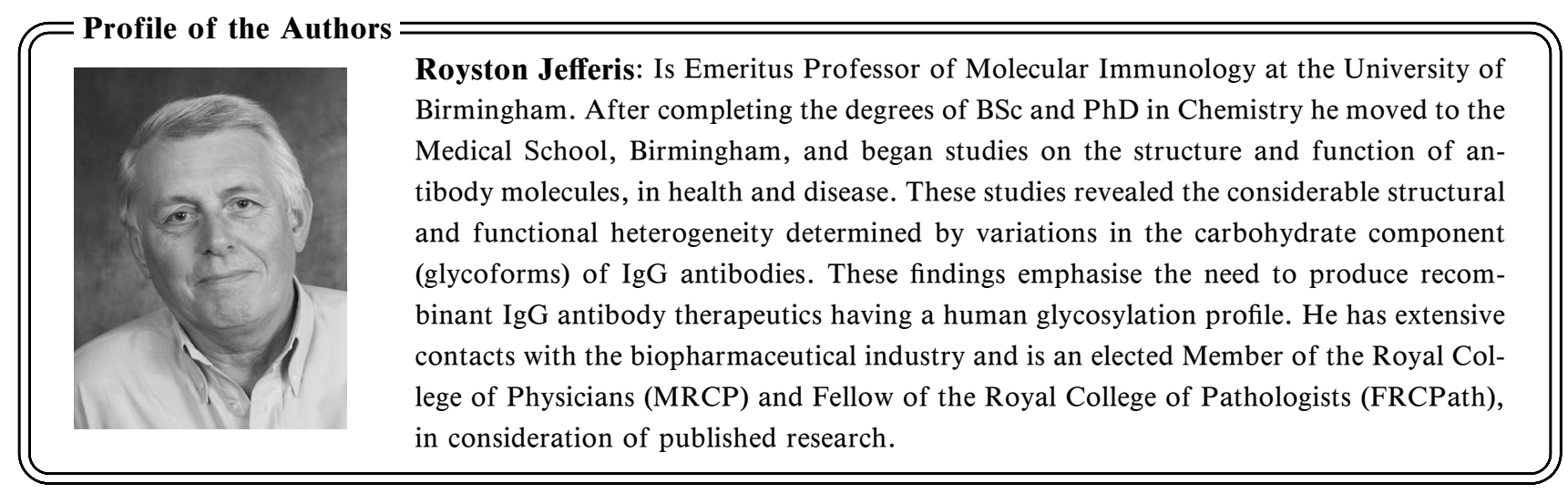

